\title{
Study the impact of chronic obstructive pulmonary diseases on bone mineral density of biomass fuel smoke exposed population and its association with hs-CRP in Rural Haryana
}

\author{
Anand Agrawal', Kamaljeet Singh ${ }^{2}$, Sunaina Kharb ${ }^{3}$, Rishi Rana ${ }^{4}$ \\ ${ }^{1}$ Professor and Head, ${ }^{2}$ Assistant Professor, ${ }^{3}$ Senior Resident, ${ }^{4}$ Specialist, Department of Respiratory Medicine, Bhagat \\ Phool Singh Government Medical College, Sonepat, Haryana, India
}

Background: Chronic obstructive pulmonary disease (COPD) has deleterious systemic impact due to spillage of inflammatory mediators in the circulation though its association with highly sensitive C-reactive protein (hs-CRP) considers as surrogate marker of inflammation is not much explored hitherto. Aims and Objectives: This study aims to study the impact of COPD on bone mineral density (BMD) and its association with hs-CRP in rural population of Haryana. Materials and Methods: Tertiary care hospital-based case-control multigroup study conducted in the Department of Respiratory Medicine, BPSGMCW, Khanpur Kalan, Sonepat, Haryana, India. A total of 150 female study subjects included and comprise in three groups, G1: Biomass exposed COPD patients; G2: Biomass smoke exposed non-COPD subjects; and G3: Non-biomass exposed healthy control. Bone density measured using dual-energy X-ray absorptiometry, hs-CRP considers as surrogate marker of inflammation. Statistical software SPSS Version 23 used to measure Chisquare/Fisher's exact test, Student's t-test, and Pearson/Spearman's rank correlation as test of significance, $\mathrm{P}<0.05$ considered as statistically significant. Results: Mean total t-score of COPD subjects was $-1.81 \pm 1.15$, significantly lower than healthy control $-0.66 \pm 1.69(P=0.000)$, however, it is near to biomass exposed non-COPD subjects $-1.74 \pm 1.14(P=0.625)$. Odds ratio for the risk of osteoporosis in the lower limb among COPD group (Lt leg: 7.07; Rt leg: 4.51) was significantly high compare to other study subjects. Mean titer of hs-CRP $(7.905 \pm 9.60$; $\mathrm{P}<0.001$ ) was significantly high in study group (G1), though its correlation with t-score was very weak $(r=-0.024 ; P=0.867)$. Conclusion: COPD has significant impact on BMD of affected population predominantly on lower limb compare to other study subjects, however, no significant association was found with inflammatory biomarkers in the decrement of bone density despite high mean titer of hs-CRP among COPD patients.

Key words: Biomass fuel smoke; Bone mineral density; Obstructive airway diseases; Osteoporosis; Tobacco smoke

\section{INTRODUCTION}

It was cited that indoor air pollution, arising from the use of biomass fuel could be one of the most important risk factors for chronic obstructive pulmonary disease (COPD) in addition to tobacco smoke and it is higher among women cooking with open fire stoves in unventilated rooms in the developing countries. ${ }^{1,2}$

\section{Access this article online}

\section{Website:}

http://nepjol.info/index.php/AJMS DOI: 10.3126/ajms.v12i11.38756 E-ISSN: 2091-0576 P-ISSN: 2467-9100

Copyright (c) 2021 Asian Journal of Medical Sciences

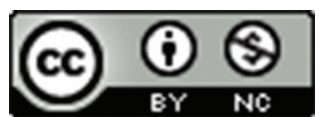

This work is licensed under a Creative Commons Attribution-NonCommercial 4.0 International License.
According to global initiative for chronic obstructive lung disease (GOLD) report, COPD defined as a disease state characterized by airflow limitation that is not fully reversible, while the airflow limitation is usually both progressive and associated with an abnormal inflammatory response of the lungs to noxious particles or gases. ${ }^{3}$

Since the past decade, COPD has been considered as a complex, multicomponent disease associated with 
pulmonary and extra pulmonary manifestations by eminent researchers. ${ }^{46}$ However, the origin of systemic inflammation present in COPD remains poorly understood and correlations in the regulation of inflammation in the pulmonary and systemic compartments are not well-documented, yet, it is clearly established that some inflammatory markers are risen in systemic circulation, ${ }^{7,8}$ while on the other hand, few researchers also linked COPD with the risk of developing osteopenia and osteoporosis which is characterized by a low bone mineral density (BMD) or microarchitectural deterioration resulting in an increased bone fragility which further potentiate the fracture risk amongwomen. ${ }^{9-11}$

Although known risk factors for developing osteoporosis are ageing, female sex, impaired nutritional status, corticosteroids, and tobacco smoking. ${ }^{12-17}$ However, limited studies conducted hitherto which were suggestive of COPD itself a risk factor for osteoporosis due to increased oxidative stress and other (pro-) inflammatory mediators in systemic circulation. ${ }^{18-22}$

\section{Aims and objectives}

Therefore, the present study has been designed to assess the risk of osteoporosis among biomass fuel smoke exposed women of rural India suffering from COPDs.

\section{MATERIALS AND METHODS}

A hospital-based cross-sectional, multigroup, case-control study was conducted in the Department of Respiratory Medicine, of BPS GMC for Women, Khanpur Kalan, Sonepat, Haryana in between May 2017 and June 2019, by included the patients visiting the OPD of department of respiratory medicine as well as patients admitted in the ward and respiratory ICU besides this control was selected through attendants of the patients. A total of 150 nonsmoker female subjects included in the study and comprise into three groups. Each group having 50 subjects.

1. Biomass fuel user, diagnosed COPD patients $(\mathrm{N}=50)$;

2. Biomass fuel users, non-COPD asymptomatic subject $(\mathrm{N}=50)$;

3. Non-biomass fuel user, healthy subjects $(\mathrm{N}=50)$

Sample size calculated using Kelsey et al., (http:/ / openepi. $\mathrm{com} /$ SampleSize/SSCC.htm) methods in observational epidemiology, with 95\% confidence interval and 80\% power. Subjects with diagnosed COPD included except those who have diabetes, pregnancy, not fit on criteria to perform PFT, HIV, renal failure, ischemic heart diseases, age $<35$ years, BMI $<18 \mathrm{~kg} / \mathrm{m}^{2}$, on oral steroid therapy for more than 3 months, sputum-positive pulmonary tuberculosis, and not given written consent.
Written informed consent of all study subjects as well as approval of the institutional ethics committee was taken before starting of the project.

All subjects were evaluated by taking detailed clinical history. If the subject has any respiratory complaint, detailed clinical examination and PFT were performed by the trained technician in the department of respiratory medicine using pulmonary function equipment (BTL-08 Spiro PC, manufactured by Health and Medical Industry, United Kingdom, calibration 03-Jun-13/003-0031080), with pre- and post-bronchodilator reports to confirm the diagnosis and staging based on the criteria of Global Initiative for GOLDs 2016 guidelines (http://www.goldcopd.org/) in required subjects.

Stage 1: Forced expiratory volume in one second (FEV1) $\geq 80 \%$ of predicted - Mild

Stage 2: FEV1 $50 \leq \mathrm{FEV} 1<80 \%$ of predicted - Moderate Stage 3: FEV1 $30 \leq \mathrm{FEV} 1<50 \%$ of predicted - Severe

Stage 4: FEV1 $<30 \%$ of predicted - Very severe

All routine as well as specific investigations were done such as ECG, lipid, profile, PFT, ABG, blood sugar, KFT, CRP, serum electrolyte $\left(\mathrm{Na}^{+}, \mathrm{K}^{+}\right.$, and $\left.\mathrm{Ca}^{++}\right)$, skiagram of chest in $\mathrm{PA}$ view, and $\mathrm{CT}$ thorax (in required patients).

CRP levels were measured quantitatively in all study subjects by taking peripheral venous blood and centrifuging it and then using Tina-quant CRPHS immunoturbidimetric assay for quantification on Roche automated clinical chemistry analyzers (ACN 217) based on the principle of measuring turbidimetrically the agglutination titer after addition of anti-CRP antibodies in the sample. ${ }^{23}$

BMD was calculated using dual-energy $\mathrm{X}$-ray absorptiometry scan. T-scores were calculated by taking the difference between a patient's measured BMD and the mean BMD in healthy young adults, matched for gender and ethnic group, and expressing the difference relative to the young adult population standard deviation. As per the WHO, osteopenia is defined as a T-score of between $>-1$ and $<-2.5$ and osteoporosis $>-2.5$ of standard deviation or $<-2.5$ with multiple fracture. ${ }^{24,25}$

\section{Statistical analysis}

Data were collected, compiled, and analyzed using standard statistical software SPSS (IBM SPSS Statistics for Windows, Version 23.0. Armonk, NY: USA), by applying Chi-square test/Fisher's exact test on categorical variables, Pearson's correlation/Spearman's rho and regression test to assess relation in between study variables, Student's t-test/Rank test on continuous variable to compare the mean, and odds ratio calculated to measure the risk, $\mathrm{P}<0.05$ was considered as statistically significant. 


\section{RESULTS}

Mean age in all study groups (G1: 56.38 $\pm 10.19 ; G 2$ : 54.6 $\pm 11.12 ; G 3: 54.14 \pm 10.72 ; \mathrm{P} \geq 0.05)$ was matched (Table 1). Body mass index of study subjects was significantly lower than control group (Table 1$)$. Mean total t-score as well as Z score significantly lower among Group 1 and Group 2 in relation to Group 3, though no significant difference observed in between Group 1 and Group 2 subjects (Table 1).

Prevalence of osteoporosis among COPD group was 28\% (14), compare to unexposed healthy individuals 10\% (5; $\mathrm{P}=0.039)$, however among biomass fuel smoke exposed subjects, osteoporosis is slightly higher $30 \%(15 ; \mathrm{P}=0.022)$ (odds ratio 3.85 ; CI: 1.27, 11.64) than COPD subjects (odds ratio 3.5 ; CI: $1.15,10.63$ ) though occurrence of unaffected bone density among biomass fuel smoke exposed subject was significantly higher 34\% (17) than subjects suffering from COPD $16 \%$ (8), in addition to this total number of subjects with affected BMD in terms of osteoporosis as well as osteopenia ( $\mathrm{T}$-score $>-1$ ) was also found significantly higher among subjects with COPD $(\mathrm{N}=42$; $84 \%$; odds ratio: 4.47 ; CI: $1.75,11.43$; with t-score $>-1$ ) in compare to biomass smoke exposed individual $(\mathrm{N}=33$; $66 \%$; $\mathrm{P}=0.032$; odds ratio: 1.65 ; CI: $0.73,3.7$; with t-score $>-1$ ) (Figure 1).

On differential analysis of BMD score, it was revealed that lumbar spine as well as limbs are markedly affected anatomical site among COPD as well as biomass fuel smoke exposed group (Table 2 and Figure 2). Odds ratio for lower limb BMD was significantly higher among subjects with COPD (Lt leg: 7.07; Rt leg: 4.51) in compare to healthy control, while for biomass smoke exposed subject, this figure is slightly lower (Lt leg: 5.06; Rt leg: 3.27) (Table 3).

In different stages of COPD (GOLD 1 and GOLD 2) as well as (GOLD 3 and GOLD 4),t-score was significantly lower than healthy control, however not affected much by the severity of diseases $(\mathrm{r}=-0.018 ; \mathrm{P}=0.901)$ (Figure 3). Prevalence of osteoporosis among mild-to-moderate COPD subjects was $26.66 \%$, odds ratio 2.4 (CI: 0.56 , $10.12 ; \mathrm{P}=0.40)$, however, in severe to very severe stage of COPD, it was $28.57 \%$, odds ratio 2.57 (CI: 0.80, 8.2; $\mathrm{P}=0.17$ ) (Table 2). Mean value of highly sensitive $\mathrm{C}$-reactive protein (hs-CRP) was significantly high among COPD (Group 1) in compare to biomass exposed non-COPD (Group 2) subjects as well as Group 3 (Healthy individual), however, it fails to show any significant correlation as well as dependency on BMD indices, $\mathrm{t}$ and $\mathrm{z}$ score $(\mathrm{r}=-0.024$; $\mathrm{P}=0.867$ ) (Table 4 and Figure 4).

\section{DISCUSSION}

Osteoporosis currently recognized as an important comorbidity in COPD patients by eminent researchers, which drag the attention of scientific fraternity to explore

\begin{tabular}{|c|c|c|c|c|c|c|c|}
\hline S. No. & $\begin{array}{c}\text { Indices } \\
\text { Mean } \pm S D\end{array}$ & $\begin{array}{c}\text { Group } 1 \\
\text { COPD } \\
N=50\end{array}$ & $\begin{array}{c}\text { Group } 2 \\
\text { Non-COPD } \\
\text { biomass smoke } \\
\text { exposed } \\
\mathrm{N}=50\end{array}$ & $\begin{array}{c}\text { Group } 3 \\
\text { Non-biomass } \\
\text { exposed } \\
\text { healthy control } \\
\mathrm{N}=50\end{array}$ & $\begin{array}{c}P \text { value } \\
\text { G1 versus } \\
\text { G3 }\end{array}$ & $\begin{array}{c}\text { P value } \\
\text { G2 } \\
\text { versus } \\
\text { G3 }\end{array}$ & $\begin{array}{c}\text { P value } \\
\text { G1 versus } \\
\text { G2 }\end{array}$ \\
\hline 1. & Age & $56.38 \pm 10.19$ & $54.6 \pm 11.12$ & $54.14 \pm 10.72$ & 0.287 & 0.834 & 0.406 \\
\hline 3. & $\mathrm{BEI}$ & $42.84 \pm 12.92$ & $47.68 \pm 31.36$ & - & - & - & 0.315 \\
\hline 4. & BMI & $20.94 \pm 4.51$ & $23.04 \pm 5.54$ & $25.90 \pm 4.16$ & 0.000 & 0.004 & 0.038 \\
\hline 5. & FEVI\% & $44.87 \pm 21.67$ & $65.03 \pm 21.49$ & $100.12 \pm 22.06$ & 0.000 & 0.000 & 0.000 \\
\hline 6. & FVC\% & $61.74 \pm 24.50$ & $67.89 \pm 21.91$ & $99.02 \pm 19.50$ & 0.000 & 0.000 & 0.189 \\
\hline 7. & FEV1/FVC & $68.08 \pm 14.22$ & $101.91 \pm 7.55$ & $106.67 \pm 9.09$ & 0.000 & 0.005 & 0.000 \\
\hline 8. & FEF25-75 & $14.11 \pm 13.04$ & $42.65 \pm 19.94$ & $75.11 \pm 26.50$ & 0.000 & 0.000 & 0.000 \\
\hline 9. & hs-CRP & $7.905 \pm 9.60$ & $3.58 \pm 5.27$ & $2.87 \pm 4.74$ & 0.001 & 0.527 & 0.006 \\
\hline 10. & T spine t-score & $-0.79 \pm 1.55$ & $-0.47 \pm 1.65$ & $0.98 \pm 2.68$ & 0.000 & 0.002 & 0.327 \\
\hline 11. & T spine $z$ score & $-0.010 \pm 2.23$ & $0.118 \pm 1.53$ & $1.44 \pm 2.77$ & 0.005 & 0.004 & 0.739 \\
\hline 12. & L spine t-score & $-1.76 \pm 1.61$ & $-1.74 \pm 1.30$ & $-0.68 \pm 2.16$ & 0.006 & 0.004 & 0.935 \\
\hline 13. & L spine $z$ score & $-1.18 \pm 1.62$ & $-1.09 \pm 1.18$ & $-0.25 \pm 2.23$ & 0.019 & 0.020 & 0.748 \\
\hline 14. & L leg t-score & $-2.23 \pm 1.08$ & $-2.116 \pm 1.06$ & $-1.28 \pm 1.15$ & 0.000 & 0.000 & 0.585 \\
\hline 15. & L leg Z score & $-1.62 \pm 1.09$ & $-1.48 \pm 0.90$ & $-0.83 \pm 1.23$ & 0.001 & 0.003 & 0.50 \\
\hline 16. & $\mathrm{R}$ leg t-score & $-2.47 \pm 1.15$ & $-2.634 \pm 1.18$ & $-1.66 \pm 1.18$ & 0.001 & 0.000 & 0.496 \\
\hline 17. & R leg Z score & $-1.83 \pm 1.20$ & $-2.01 \pm 1.09$ & $-1.21 \pm 1.28$ & 0.014 & 0.001 & 0.447 \\
\hline 18. & Total t-score & $-1.81 \pm 1.150$ & $-1.74 \pm 1.14$ & $-0.662 \pm 1.69$ & 0.000 & 0.000 & 0.625 \\
\hline 19. & Total Z score & $-1.16 \pm 1.34$ & $-1.11 \pm 0.99$ & $-0.21 \pm 1.78$ & 0.000 & 0.000 & 0.778 \\
\hline
\end{tabular}

BEI: Biomass exposure index (Biomass average hours spent on cooking per day multiplied by the number of years of cooking; Developed by Behera et al., ${ }^{41}$ ), BMI: Body mass index, FEV1: Forced expiratory volume in one second, FVC: Forced vital capacity, FEF25-75: Forced expiratory flow at 25-75\% of forced vital capacity, hs-CRP: Highly sensitive C-reactive protein. T: Thoracic, L-Spine: Lumbar spine, L leg: Left leg, R leg: Right leg, COPD: Chronic obstructive pulmonary disease 


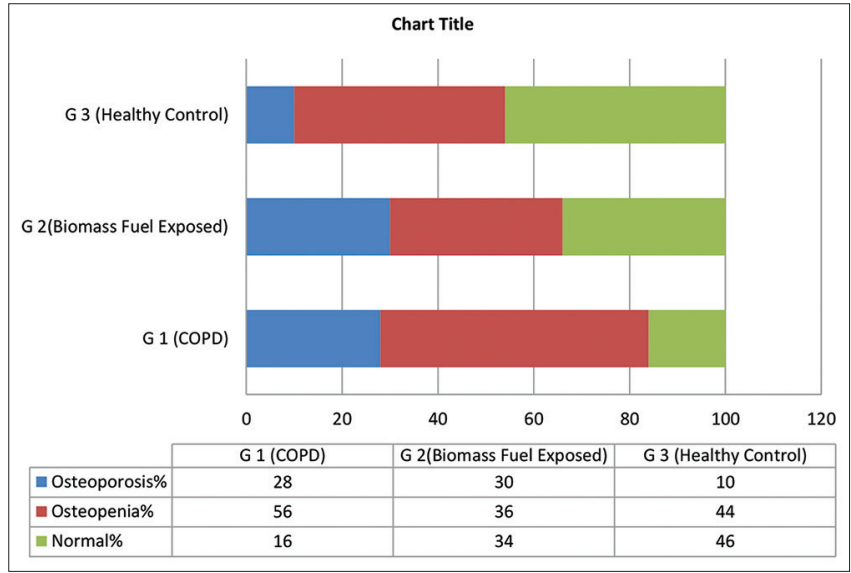

Figure 1: Bar diagram shows distribution of subjects in percentage ( $n=50$ in each group) on basis of grading of bone mineral density

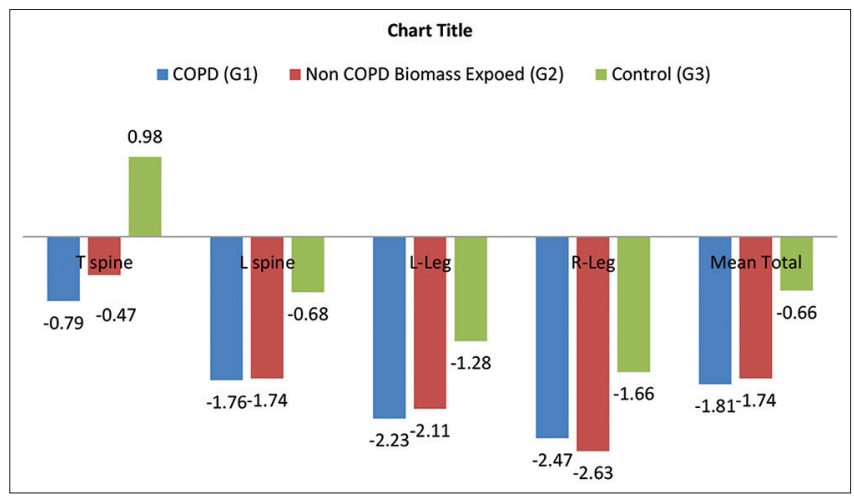

Figure 2: Bar diagram shows t-score of bone mineral density at different anatomical site in study groups

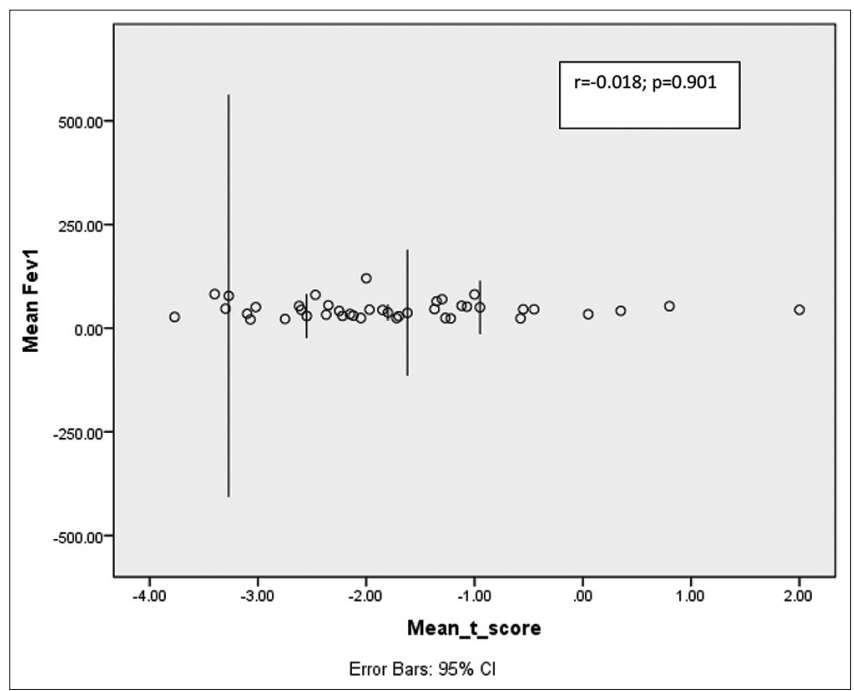

Figure 3: Scattered plot of correlation in between mean FEV1 and mean t-score in chronic obstructive pulmonary disease. FEV1: Forced expiratory volume in one second

the idea in a more comprehensive way. ${ }^{26,27}$ In the present study, we found that BMD markedly affected by the presence of COPD in study subjects, however in a parallel group, those exposed to biomass fuel smoke without

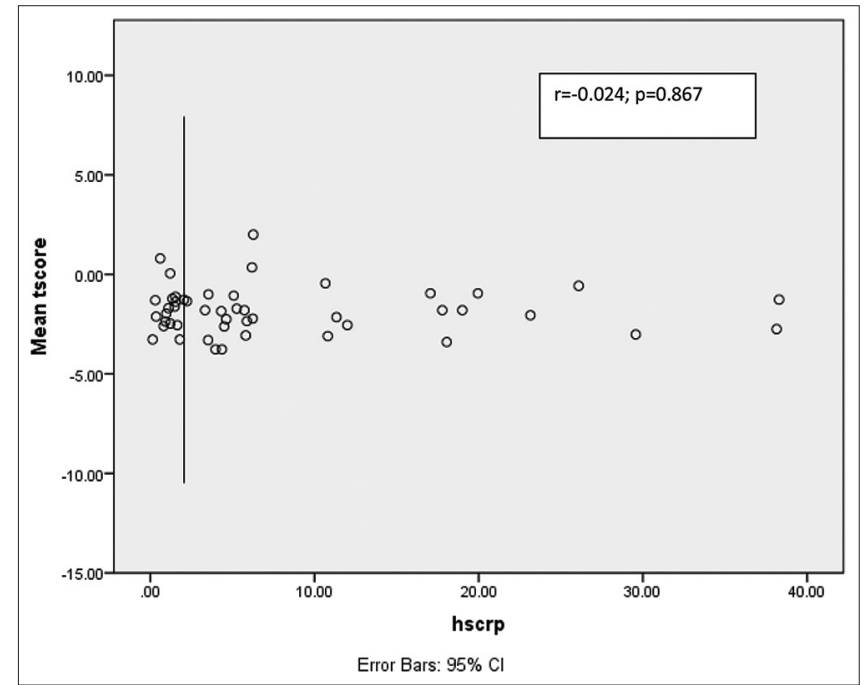

Figure 4: Scattered plot of correlation in between mean t-score and highly sensitive C-reactive protein in chronic obstructive pulmonary disease

COPD, have similar presentation on BMD analysis. In both study groups, the mean $\mathrm{t}$ value; which is considered as diagnostic criteria for the osteoporosis, was significantly lower than healthy control group. In a recent cross sectional study conducted in Japan revealed significant association of COPD with decrement in BMD. However statistical robustness of the results lacking due to the absence of control group. ${ }^{28}$ Another cohort study conducted by Goto et al., in Japan by including 103 patients with COPD found contrary results, as progression of COPD is not directly related with progression of osteoporosis. ${ }^{29}$ A similar case-control study conducted by Nayyar et al., found significant association of COPD with osteoporosis, however, they have not analyzed the impact of smoke produced by biomass fuel or tobacco on bone health as a major confounder, unlike the present study. ${ }^{30} \mathrm{On}$ analyzing the data of various study groups in the present study it was observed that COPD may have very little independent role in the decrement of bone mineral density, as it will enhance the risk of osteoporosis among subjects with COPD, equal to non-COPD biomass smoke exposed study population, however, risk of decrement in BMD as a manifestation of osteoporosis including osteopenia, was found significantly higher among subjects suffering from COPD compare to other study subjects. While prevalence of osteopenia among controlled group of healthy individual was nearly similar to other study groups may be due to ageing. In a prospective study conducted by Hattiholi and Gaude included 102 COPD subjects observe that $66 \%$ cases were osteoporotic and predominantly they belongs to stage three and four of COPD ${ }^{31}$ However in present study there was no significance difference in the decrement of BMD among various stages of airway obstruction (Table 3). According to Inoue et al., in a previous systematic review including 
a total of 775 COPD patients from 13 studies, the overall prevalence of osteoporosis defined by low BMD was $35.1 \%$ on average, ranging from $8.7 \%$ to $69 \%$. In addition to this, COPD significantly increased the risk of osteoporosis (low BMD) 1.9-fold. ${ }^{32}$ However, in the present study, the prevalence of osteoporosis is $28 \%$ in COPD subjects with 3.5-fold increased risk, which is slightly higher to above cited studies somehow due to inclusion of only female subjects; more prone to osteoporosis after menopause while COPD somehow expedites the process of decaying during the course (Figure 1).

\begin{tabular}{|c|c|c|c|}
\hline & \multicolumn{2}{|c|}{$\begin{array}{l}\text { COPD } \\
\mathrm{N}=50\end{array}$} & \multirow{2}{*}{$\begin{array}{c}\text { Healthy } \\
\text { control }\end{array}$} \\
\hline & $\begin{array}{c}\text { GOLD } 1 \text { and } 2 \\
N=15\end{array}$ & $\begin{array}{c}\text { GOLD } 3 \\
\text { and } 4 \\
N=35\end{array}$ & \\
\hline $\begin{array}{l}\text { Mean } \\
\text { t-score } \pm S D\end{array}$ & $-1.79 \pm 1.10$ & $-1.82 \pm 1.18$ & $-0.66 \pm 1.69$ \\
\hline Osteoporosis & $4(26.66 \%)$ & $10(28.57)$ & $5(10 \%)$ \\
\hline Odds ratio & 2.4 & 2.57 & - \\
\hline $\mathrm{Cl}$ & $0.56 ; 10.12$ & $0.80 ; 8.2$ & - \\
\hline $\begin{array}{l}\text { P value } \\
\text { GOLD } 1 \text { and } 2 \\
\text { versus } \\
\text { GOLD 3and4 }\end{array}$ & \multicolumn{2}{|c|}{0.941} & \\
\hline $\begin{array}{l}\text { P value } \\
\text { case versus } \\
\text { control }\end{array}$ & 0.018 & 0.001 & - \\
\hline
\end{tabular}

GOLD 1 and 2 and 3 and 4 : Stages of COPD, CI: Confidence interval, GOLD: Global initiative for chronic obstructive lung disease, BMD: Bone mineral density, COPD: Chronic obstructive pulmonary disease
According to researcher, smoke associated to alterations in the receptor activator of nuclear factor kappa-B (RANK), receptor activator of nuclear factor kappa-B ligand (RANKL), and osteoprotegerin (OPG) system (RANK-RANKL-OPG system), and direct cellular effects on bone cells in exposed population..$^{33,34}$ Similarly, in recent research conducted by Saha et al., by including 74 pre-menopausal women from East India using biomass and 65 control women who cooked with cleaner liquefied petroleum gas, reveal that the levels of CD4 $(+)$ and $\mathrm{CD} 19$ $(+)$ lymphocytes and circulating granulocytes with elevated levels of membrane-bound RANKL (receptor activator of nuclear factor-kappa ligand 1) were higher in biomass users. The serum levels of RANKL were increased by $41 \%$, whereas serum osteoprotegerin (OPG) was reduced by $22 \%$ among biomass users, suggesting an increased risk of bone resorption and consequent osteoporosis in biomass exposed women of a child-bearing age ${ }^{35}$ Moreover, role of inflammation in COPD-associated osteoporosis, with lower BMD have been shown to exhibit higher levels of CRP and inflammatory cytokines such as TNF- $\alpha$, IL- 1 , and IL- $6 .{ }^{32}$ In present study the titer of hs-CRP was significantly high among COPD group compared to healthy control as well as non COPD biomass smoke exposed individual. Though very weak negative correlation was found in between hsCRP and mean total t-score among COPD. In an old metaanalysis, pooled data across 86 studies, enrolling 40,753 subjects reveal that smokers had significantly reduced bone mass compared with non-smokers (never and former smokers) at all bone sites. Smoking increases the lifetime risk of developing a vertebral fracture by $13 \%$ in women and $32 \%$ in men. At the hip, smoking is estimated to

\begin{tabular}{|c|c|c|c|c|c|c|c|c|c|}
\hline \multirow[t]{2}{*}{ AS } & \multicolumn{3}{|c|}{$\begin{array}{l}\text { Prevalence of osteoporosis } \\
\text { (T-score }>-2.5)\end{array}$} & \multicolumn{3}{|c|}{ P-value } & \multicolumn{3}{|c|}{ Odds ratio with $\mathrm{Cl}$} \\
\hline & $\begin{array}{c}\mathbf{G 1} \\
\mathrm{N}=50\end{array}$ & $\begin{array}{c}\mathbf{G 2} \\
\mathrm{N}=50\end{array}$ & $\begin{array}{c}\mathbf{G 3} \\
\mathrm{N}=50\end{array}$ & $\begin{array}{c}\text { G1 } \\
\text { versus } \\
\text { G3 }\end{array}$ & $\begin{array}{c}\text { G2 } \\
\text { versus } \\
\text { G3 }\end{array}$ & $\begin{array}{c}\text { G1 } \\
\text { versus } \\
\text { G2 }\end{array}$ & $\begin{array}{c}\text { G1 } \\
\text { versus } \\
\text { G3 }\end{array}$ & $\begin{array}{c}\text { G2 } \\
\text { versus } \\
\text { G3 }\end{array}$ & $\begin{array}{c}\text { G1 } \\
\text { versus } \\
\text { G2 }\end{array}$ \\
\hline TS & $5(10 \%)$ & $6(12 \%)$ & $0(00)$ & 0.05 & 0.02 & 0.99 & $\begin{array}{l}11.11 \\
(0.59, \\
209.1)\end{array}$ & $\begin{array}{c}13.5 \\
(0.73 \\
248.6)\end{array}$ & $\begin{array}{l}0.814 \\
(0.23, \\
2.860)\end{array}$ \\
\hline LS & $18(36 \%)$ & $17(34 \%)$ & $6(12 \%)$ & 0.007 & 0.017 & 0.99 & $\begin{array}{c}4.31 \\
(1.54 \\
12.06)\end{array}$ & $\begin{array}{c}3.77 \\
(1.34 \\
10.63)\end{array}$ & $\begin{array}{l}1.09 \\
(0.47, \\
2.48)\end{array}$ \\
\hline LL & $22(44 \%)$ & $18(36 \%)$ & $5(10 \%)$ & 0.0002 & 0.003 & 0.54 & $\begin{array}{c}7.07 \\
(2.40 \\
20.81)\end{array}$ & $\begin{array}{l}5.06 \\
(1.70 \\
15.05)\end{array}$ & $\begin{array}{r}1.39 \\
(0.62, \\
3.11)\end{array}$ \\
\hline $\mathrm{RL}$ & $28(56 \%)$ & $24(48 \%)$ & $11(22 \%)$ & 0.001 & 0.01 & 0.54 & $\begin{array}{c}4.51 \\
(1.88 \\
10.79)\end{array}$ & $\begin{array}{c}3.27 \\
(1.37 \\
7.80)\end{array}$ & $\begin{array}{l}1.37 \\
(0.62 \\
3.02)\end{array}$ \\
\hline MT & $14(28 \%)$ & $15(30 \%)$ & $5(10 \%)$ & 0.039 & 0.022 & 0.99 & $\begin{array}{l}3.5 \\
(1.15 \\
10.63)\end{array}$ & $\begin{array}{l}3.85 \\
(1.27 \\
11.64)\end{array}$ & $\begin{array}{l}0.90 \\
(0.38 \\
2.15)\end{array}$ \\
\hline
\end{tabular}

AS: Anatomical site, TS: Thoracic spine, LS: Lumber spine, LL: Left leg, RL: Right leg, MT: Mean total, G1: Subjects with COPD, G2: Subjects exposed to biomass fuel smoke non-COPD, G3: Non-biomass fuel smoke healthy subjects, Cl: Confidence interval, COPD: Chronic obstructive pulmonary disease 


\begin{tabular}{|c|c|c|c|c|c|c|c|c|c|c|}
\hline \multirow[t]{3}{*}{ Indices } & \multicolumn{5}{|c|}{ T-score } & \multicolumn{5}{|c|}{ Z score } \\
\hline & \multicolumn{2}{|c|}{ Correlation } & \multicolumn{3}{|c|}{ Regression } & \multicolumn{2}{|c|}{ Correlation } & \multicolumn{3}{|c|}{ Regression } \\
\hline & $r$ & $p$ & $F$ & B & $p$ & $\mathbf{R}$ & $\mathbf{P}$ & $F$ & B & $\mathbf{P}$ \\
\hline FEV1 & -0.018 & 0.901 & 0.016 & -0.018 & 0.901 & 0.022 & 0.881 & 0.022 & 0.022 & 0.881 \\
\hline FVC & 0.026 & 0.860 & 0.031 & 0.026 & 0.860 & 0.053 & 0.715 & 0.135 & 0.053 & 0.715 \\
\hline $\begin{array}{l}\text { FEV1/ } \\
\text { FVC }\end{array}$ & -0.035 & 0.811 & 0.058 & -0.035 & 0.811 & -0.028 & 0.846 & 0.038 & -0.028 & 0.846 \\
\hline FEF25-75 & 0.044 & 0.761 & 0.094 & 0.044 & 0.761 & 0.060 & 0.680 & 0.173 & 0.060 & 0.680 \\
\hline hs-CRP & -0.024 & 0.867 & 0.090 & -0.043 & 0.766 & 0.093 & 0.52 & 0.001 & -0.005 & 0.972 \\
\hline $\mathrm{BEI}$ & -0.102 & 0.479 & 0.508 & -0.102 & 0.479 & -0.046 & 0.749 & 0.104 & -0.046 & 0.749 \\
\hline BMI & -0.108 & 0.453 & 0.572 & -0.108 & 0.453 & -0.117 & 0.420 & 0.661 & -0.117 & 0.420 \\
\hline
\end{tabular}

increase lifetime fracture risk by $31 \%$ in women and $40 \%$ in men. ${ }^{36,37}$ Although in one prospective study conducted in Spain by including 248 patients over 2 years promulgate that vertebral column fracture is common in COPD patients. ${ }^{38} \mathrm{In}$ a similar recently published large retrospective population-based study conducted in Taiwan by including 11312 patients with COPD, found that the most common site specific fracture were vertebral, femoral, and forearm $(32.4 \% ; 31 \%$; and $12 \%)$, respectively. ${ }^{39}$ However, in the present study, lumbar spine as well as lower limb were significantly affected in subjects with COPD, compare to control, as well as risk of osteoporosis was quite higher than healthy subjects; perhaps be due to disuse atrophy of lower limb in debilitating moribund patients. Overall risk of osteoporosis was also found significantly high in compare to healthy subjects, however, similar risk was found among non-COPD biomass smoke exposed subjects at different anatomical level of skeleton except lower limb and lumber spine. Moreover, titer of hs-CRP was significantly high among COPD subjects in compare to healthy as well as non-COPD biomass smoke exposed individuals; though it was not correlated significantly with the decrement in BMD. It was cited that smoking has been shown to increase cortisol level, leading to hypercortisolism, a high blood level of glucocorticoid in smokers alters bone metabolism and decreases bone mass either directly by changing the osteoblast and osteoclast activities or indirectly by altering the gastrointestinal as well as renal absorption of calcium. Besides this in women, tobacco smoking enhances estrogen metabolism resulting in a lower level of estradiol which may lead to early osteoporosis, ${ }^{40}$ however, it is not yet proved in relation to biomass smoke; need further research for better understanding of its pathophysiology at molecular level. Therefore, according to the present study, it can be stated that COPD has significant impact on BMD in compare to other study subjects, however, risk of osteoporosis is similar among COPD and biomass fuel smoke exposed individual compare to healthy population though lower limb involvement was predominant in COPD patients compare to other study subjects perhaps due to sedentary life style among them.

\section{CONCLUSION}

COPD has significant risk of osteoporosis in compare to healthy population, as well as increase the risk of decrement of BMD of lower limb in compare to other study groups, though it was not proved as an independent risk factor for it. According to the present study, biomass smoke also has significant deleterious impact on bone health in pre-COPD stage similar to patients with diagnosed COPD. Moreover, systemic inflammation was pronounced in COPD subjects compare to other study groups, though there was very weak inverse correlation found in between decrement of BMD and titer of inflammatory mediator (hs-CRP) among COPD subjects. In addition to this, airflow limitation has no significant correlation with decrement in BMD, although risk of osteoporosis is slightly higher in advance stage compare to early stage of COPD.

\section{ACKNOWLEDGMENT}

Nil.

\section{REFERENCES}

1. Pauwels RA, Buist AS, Calverley PM, Jenkins CR, Hurd SS and GOLD Scientific Committee. Global strategy for the diagnosis, management, and prevention of chronic obstructive pulmonary disease. NHLBI/WHO Global Initiative for Chronic Obstructive Lung Disease (GOLD) Workshop summary. Am J Respir Crit Care Med. 2001;163(5):1256-1276.

http://doi.org/10.1164/ajrccm.163.5.2101039

2. Salvi SS and Barnes PJ. Chronic obstructive pulmonary disease in nonsmokers. Lancet. 2009;374(9691):733-743.

http://doi.org/10.1016/S0140-6736(09)61303-9 
3. Salvi SS and Barnes PJ. Is exposure to biomass smoke the biggest risk factor for COPD globally? Chest. 2010;138(1):3-6. http://doi.org/10.1378/chest.10-0645

4. Agusti A, Sobradillo P and Celli B. Addressing the complexity of chronic obstructive pulmonary disease: From phenotypes and biomarkers to scale-free networks, systems biology, and P4 medicine. Am J Respir Crit Care Med. 2011;183(9):1129-1137. http://doi.org/10.1164/rccm.201009-1414PP

5. Barnes PJ and Celli BR. Systemic manifestations and comorbidities of COPD. Eur Respir J. 2009;33(5):1165-1185. http://doi.org/10.1183/09031936.00128008

6. Murray CJ and Lopez AD. Alternative projections of mortality and disability by cause 1990-2020: Global burden of disease study. Lancet. 1997;349(9064):1498-1504. http://doi.org/10.1016/S0140-6736(96)07492-2

7. Agust/ A. Systemic effects of chronic obstructive pulmonary disease: What we know and what we don020: Global burden of Proc Am Thorac Soc. 2007;4(7):522-525. http://doi.org/10.1513/pats.200701-004FM

8. Wouters EF. Local and systemic inflammation in chronic obstructive pulmonary disease. Proc Am Thorac Soc. 2005;2(1):26-33.

http://doi.org/10.1513/pats.200408-039MS

9. Papaioannou A, Parkinson W, Ferko N, Probyn L, loannidis G, Jurriaans $E$, et al. Prevalence of vertebral fractures among patients with chronic obstructive pulmonary disease in Canada. Osteoporos Int. 2003;14(11):913-917.

http://doi.org/10.1007/s00198-003-1449-5

10. Jorgensen NR, Schwarz P, Holme I, Henriksen BM, Petersen LJ and Backer V. The prevalence of osteoporosis in patients with chronic obstructive pulmonary disease: A cross sectional study. Respir Med. 2006;101(1):177-185. http://doi.org/10.1016/j.rmed.2006.03.029

11. Sarkar M, Bhardwaj R, Madabhavi I and Khatana J. Osteoporosis in chronic obstructive pulmonary disease. Clin Med Insights Circ Respir Pulm Med. 2015;9:5-21. http://doi.org/10.4137/CCRPM.S22803

12. Graat-Verboom L, Wouters EF, Smeenk FW, Van den Borne BE, Lunde R and Spruit MA. Current status of research on osteoporosis in COPD: A systematic review. Eur Respir J. 2009;34(1):209-218.

http://doi.org/10.1183/09031936.50130408

13. Katsura $\mathrm{H}$ and Kida $\mathrm{K}$. A comparison of bone mineral density in elderly female patients with COPD and bronchial asthma. Chest. 2002;122(6):1949-1955.

http://doi.org/10.1378/chest.122.6.1949

14. Biskobing DM. COPD and osteoporosis. Chest. 2002;121(2): 609-620.

http://doi.org/10.1378/chest.121.2.609

15. Cummings SR, Nevitt MC, Browner WS, Stone K, Fox KM, Ensrud KE, et al. Risk factors for hip fracture in white women. Study of osteoporotic fractures research group. N Engl J Med. 1995;332(12):767-773.

http://doi.org/10.1056/NEJM199503233321202

16. Law MR and Hackshaw AK. A meta-analysis of cigarette smoking, bone mineral density and risk of hip fracture: Recognition of a major effect. BMJ. 1997;315(7112):841-846. http://doi.org/10.1136/bmj.315.7112.841

17. Divo MJ, Celli BR, Poblador-Plou B, Calderlderlou B, C A, deTorres JP, Gimeno-Feliu LA, et al. Chronic Obstructive Pulmonary Disease (COPD) as a disease of early aging: Evidence from the
EpiChron Cohort. PLoS One. 2018;13(2):e0193143. http://doi.org/10.1371/journal.pone.0193143

18. Ferrari SL, Ahn-Luona L, Garnero P, Humphries SE and Greenspan SL. Two promoter polymorphisms regulating interleukin-6 gene expression are associated with circulating levels of C-reactive protein and markers of bone resorption in postmenopausal women. J Clin Endocrinol Metab. 2003;88(1):255-259.

http://doi.org/10.1210/jc.2002-020092

19. Jilka RL, Hangoc C, Girasole G, Passeri G, Williams DC, Abrams JS, et al. Increased osteoclast development after estrogen loss: Mediation by interleukin-6. Science. 1992;257(5066):88-91. http://doi.org/10.1126/science.1621100

20. Poli V, Balena R, Fattori E, Markatos A, Yamamoto M, Tanaka H, et al. Interleukin deficient mice are protected from bone loss caused by estrogen depletion. EMBO J. 1994;13(5):189-196.

21. Scheidt-Nave $C$, Bismar $H$, Leidig-Bruckner $G$, Woitage $H$, Seibel MJ, Zieggler R, et al. Serum Interleukin-6 is a major predictor of bone loss in women specific to the first decade past menopause. J Clin Endocrinol Metab. 2001;86(5):2032-2042. http://doi.org/10.1210/jcem.86.5.7445

22. John M, Hoernig S, Doehner W, Okonko DD, Witt C and Anker SD. Anemia and inflammation in COPD. Chest. 2005;127(3):825-829. http://doi.org/10.1378/chest.127.3.825

23. Eda S, Kaufmann J, Roos W and Pohl S. Development of a new microparticle-enhanced turbidimetric assay for C-reactive protein with superior features in sensitivity and dynamic range. $\mathrm{J}$ Clin Lab Anal. 1998;12(3):137-144.

http://doi.org/10.1002/(sici)1098-2825(1998)12:3<137::aidjcla2>3.0.co;2-6

24. World Health Organization. Assessment of fracture risk and its application to screening for postmenopausal osteoporosis. Report of a WHO Study Group. World Heath Organ Tech Rep Ser. 1994;843:1-129.

25. Kanis JA and Gluer CC. An update on the diagnosis and assessment of osteoporosis with densitometry. The committee of scientific advisors, international osteoporosis foundation. Osteoporos Int. 2000;11(3):192-202.

http://doi.org/10.1007/s001980050281

26. Liang $B$ and Feng $Y$. The association of low bone mineral density with systemic inflammation in clinically stable COPD. Endocrine. 2012;42(1):190-195.

http://doi.org/10.1007/s12020-011-9583-x

27. Cooper C, Atkinson EJ, O12020-011-9583-x0-011-9583 ${ }^{\text {rd }}$. Incidence of clinically diagnosed vertebral fractures: A population-based study in Rochester, Minnesota, 1985-1989. J Bone Miner Res. 1992;7(2):221-227. http://doi.org/10.1002/jbmr.5650070214

28. Sakurai-lesato $\mathrm{Y}$, Kawata $\mathrm{N}$, Tada $\mathrm{Y}$, lesato $\mathrm{K}$, Matsuura $\mathrm{Y}$, Yahaba M, et al. The relationship of bone mineral density in men with chronic obstructive pulmonary disease classified according to the global initiative for chronic obstructive lung disease (GOLD) combined chronic obstructive pulmonary disease (COPD) assessment system. Intern Med. 2017;56(14):1781-1790 http://doi.org/10.2169/internalmedicine.56.6910

29. Goto K, Ogawa E, Shimizu K, Makita H, Suzuki H, Kawata Y, et al. Relationship of annual change in bone mineral density with extent of emphysematous lesions and pulmonary function in patients with COPD. Int $\mathrm{J}$ Chron Obstruct Pulmon Dis. 2018;13:639-644. http://doi.org/10.2147/COPD.S153750

30. Nayyar N, Sood RG, Sarkar M, Tomar A, Thakur V and Bhoil R. 
Prevalence of osteoporosis and osteopenia in stable patients of chronic obstructive pulmonary disease in Sub-Himalayan region of Himachal Pradesh, India. J Family Med Prim Care. 2017;6(3):595-599.

http://doi.org/10.4103/2249-4863.222013

31. Hattiholi J and Gaude GS. Prevalence and correlates of osteoporosis in chronic obstructive pulmonary disease patients in India. Lung India. 2014;31(3):221-227.

http://doi.org/10.4103/0970-2113.135759

32. Inoue D, Watanabe R and Okazaki R. COPD and osteoporosis: Links, risks, and treatment challenges. Int $\mathrm{J}$ Chron Obstruct Pulmon Dis. 2016;11:637-648.

http://doi.org/10.2147/COPD.S79638

33. Bai $P$, Sun $Y$, Jin J, Hou J, Li R, Zhang Q, et al. Disturbance of the OPG/RANK/RANKL pathway and systemic inflammation in COPD patients with emphysema and osteoporosis. Respir Res. 2011;12(1):157.

http://doi.org/10.1186/1465-9921-12-157

34. Yoon V, Maalouf NM and Sakhaee K. The effects of smoking on bone metabolism Osteoporos Int. 2012;23(8):2081-2092.

http://doi.org/10.1007/s00198-012-1940-y

35. Saha H, Mukherjee B, Bindhani B and Ray MR. Changes in RANKL and osteoprotegerin expression after chronic exposure to indoor air pollution as a result of cooking with biomass fuel. $J$ Appl Toxicol. 2016;36(7):969-976.

http://doi.org/10.1002/jat.3275
36. Ward KD and Klesges RC. A meta-analysis of the effects of cigarette smoking on bone mineral density. Calcif Tissue Int. 2001;68(5):259-270.

http://doi.org/10.1007/BF02390832

37. Yamauchi $Y$, Yasunaga $H$, Sakamoto $Y$, Hasegawa $W$, Takeshima $\mathrm{H}$, Urushiyama $\mathrm{H}$, et al. Mortality associated with bone fractures in COPD patients. Int J Chron Obstruct Pulmon Dis. 2016;11:2335-2340. http://doi.org/10.2147/COPD.S112142

38. Pascual-Guardia S, Badenes-Bonet D, Martin-Ontiyuelo C, Zuccarino F, Mar M-Corral J, Rodrr Marno F, Marrino Fital admissions and mortality in patients with COPD exacerbations and vertebral body compression fractures. Int J Chron Obstruct Pulmon Dis. 2017;12:1837-1845. http://doi.org/10.2147/COPD.S129213

39. Liao KM, Liang FW and Li CY. Risks of all-cause and site-specific fractures among hospitalized patients with COPD. Medicine (Baltimore). 2016;95(40):e5070. http://doi.org/10.1097/MD.0000000000005070

40. Al-Bashaireh AM, Haddad LG, Weaver M, Chengguo X, Kelly DL and Yoon S. The effect of tobacco smoking on bone mass: An overview of pathophysiologic mechanisms. J Osteoporos. 2018;2018:1206235. http://doi.org/10.1155/2018/1206235

41. Behera D, Jindal SK. Respiratory symptoms in Indian women using domestic cooking fuels. Chest. 1991; 100:385-8.

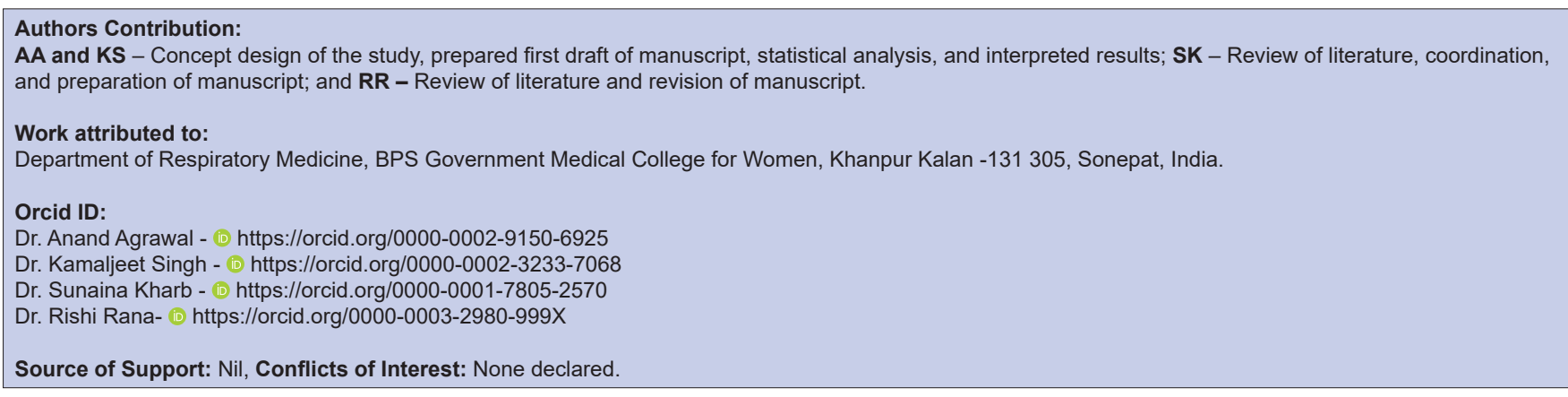

